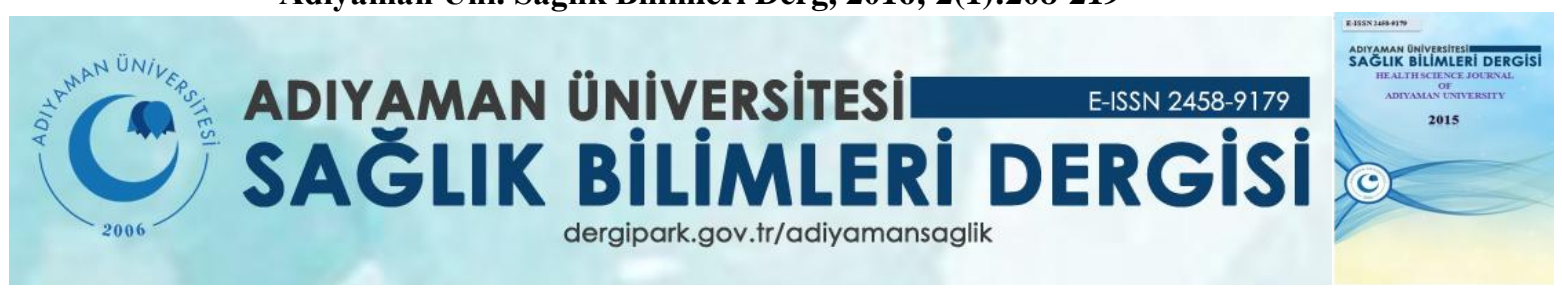

\title{
Araştırma/Research
}

\section{Sıçanlarda östrüs siklusuda endometriyum dokusunda humoral savunma hücrelerinin dağılımı,}

\author{
Alper YALÇIN ${ }^{1}$, Mehmet KANTER ${ }^{2}$ \\ ${ }^{1}$ Adıyaman Üniversitesi Histoloji Anabilim Dalı. \\ ${ }^{2}$ Emekli
}

\section{ÖZ}

Amaç: Bu çalışmada, östrüs siklusu (proöstrüs, östrüs, metöstrüs, diöstrüs) boyunca endometriyumda görülen humoral savunma sistemi hücreleri dağılımının histokimyasal olarak belirlenmesi amaçlanmıştır.

Yöntem: Ağırlıkları 200-250g arasında değişen üç aylık 28 adet Wistar Albino dişi sıçan kullanıldı. Sıçanlar, östrüs siklus evrelerine göre her grupta 7 adet sıçan olacak şekilde 4 gruba ayrıldı. Östrüsun dönemlerini belirlemek için, vajinal smear yöntemi uygulandı. Alınan sürüntü temiz bir lam üzerine yayılarak metilen mavisi ile boyandı. Bu bloklardan alınan $6 \mu$ kalınlığındaki kesitler plazma hücrelerini belirlemek için metil greenpironin boyama yöntemi uyguland.

Bulgular: Plazma hücreleri en fazla sayıda proöstrüs grubundaki sıçanlarda görüldü. Plazma hücre sayısının sırasıyla östrüs, metöstrus ve diöstrus evrelerine doğru oldukça azaldı ̆̆ 1 belirlendi.

Sonuç: Endometriyumdaki humoral savunma sistemi hücrelerinin, östrüs siklusunun farklı evrelerinde değişik dağılımlar gösterdiği sonucuna varıldı. Östrüs siklusunun, hormonal regülasyonun kontrolü altında birbirini takip eden farklı evreler içerdiği ve evreler arasındaki immunolojik tepkilerdeki farklılı̆̆ın yine bu hormonal kontroltü altında ortaya çıktığı kanaatine varıldı.

Anahtar kelimeler: humoral savunma sistemi, östrüs siklusu, endometriyum.

\begin{tabular}{l}
\hline Yazışmadan Sorumlu Yazar \\
\hline Alper Yalçın \\
Adıyaman Üniversi Tıp Fakültesi Histoloji \\
Anabilim Dalı. \\
Tel : +90 05435828463 \\
Email: alperyalcin0171@hotmail.com \\
\hline
\end{tabular}

DOI: 10.30569/adiyamansaglik.418086

\begin{tabular}{ll}
\hline Geliş Tarihi: & $\mathbf{2 4 . 0 4 . 2 0 1 8}$ \\
\hline Kabul Tarihi: & $\mathbf{0 9 . 0 5 . 2 0 1 8}$ \\
\hline
\end{tabular}




\title{
Distribution of humoral defense cells in the endometrium during the estrus cycle
} in rats

\begin{abstract}
Purpose: In this study, it was histochemically aimed to determine the distribution of humoral defense system cells in the endometrium during oestrous cycle (proöstrüs, östrüs, metöstrüs, diöstrüs).
\end{abstract}

Method: In this study, 28 Wistar Albino female rats (used), weighing 200-250 g and 3 months old, were examined. The rats were divided into 4 groups according to the estrous cycle stages as 7 rats at each group. Vaginal smear method was used to determine estrous periods. The receiving material was spread on a clean lam and painted with methylene blue. Methyl green-pyronin staining method was used to identify plasma cells of $6 \mu$ thickness sections from parafine blocks.

Results: The largest number of plasma cells were seen in the proestrous group.

Plasma cell numbers were significantly reduced towards oestrous, metrostrus and diestrus stages, respectively.

Conclusion: Humoral defense system cells in the endometrium were found to show different distributions at different stages of the oestrous cycle. The oestrous cycle contains different stages under the control of hormonal regulation. It was concluded that the differences in the immunological responses between these stages also appeared under this hormonal control.

Key words: humoral defense system, estrous cycle, endometrium. 


\section{Giriş}

Lenf nodülleri, bademcikler, dalak ve timüs gibi lenfatik dokular, immunolojik özellikleri yönünden oldukça fazla çalışılmıştır. Bununla birlikte endometriyum gibi lenfatik olmayan organlardaki immun kompetan hücreler ve fonksiyonları hakkında çok şey bilinmemektedir (1). Dişi genital organların immunolojik tepkileri diğer lokal mukozal immunolojik sistemlerle (solunum sistemi, gastrointestinal sistem v.s) karşılaştırıldığında spesifiktir ve östrüs siklusunun evrelerine göre değişiklik göstermektedir (2).

Birçok araştırıcı genital sistem organlarından olan uterusun, ince barsak, meme bezi ve karaciğer gibi mukozal immun sistemin bir parçası olduğunu belirtmişlerdir $(3,4)$. Östrüs siklusunda, endometriyal dokudaki immunolojik tepkide değişiklik olmaktadır. İmmun sistem hücreleri ve spesifik immunglobulinler, yabancı maddeleri spesifik olarak kontrol eder, yıkımlar ve üreme sisteminden uzaklaştırır (5). Östrüsde, serviks uterinin açılmasına paralel olarak patojenlerin uterus içerisine girmesi daha kolay olduğu için, uterusun immun fonksiyonu maksimum derecede artmasına karşın, diöstrüsde ise immun tepki en alt düzeye inmektedir (3). Uterus, birçok önemli tip antijene maruz kalan bir organ olmasına rağmen bu organdaki antijen sunumu ile ilgili çok az şey bilinmektedir (6).

$\mathrm{Bu}$ çalışmada, östrüs siklusu (proöstrüs, östrüs, metöstrüs, diöstrüs) boyunca endometriyumda görülen humoral savunma sistemi hücreleri dağılımının histoklimyasal olarak belirlenmesi amaçlanmıştır. 


\section{Gereç ve Yöntemler}

Bu çalışmada, ağırlıkları 200-250 g arasında değişen üç aylık 28 adet Wistar Albino dişi sıçan kullanıldı. Sıçanlar, östrüs siklus evrelerine göre, her grupta yedi adet hayvan olmak üzere dört ayrı gruba ayrıldı. Ayrı kafeslerde gruplar halinde bulunan hayvanlar, standart sıçan yemi ve su ile ad libitum beslenmeye tabi tutuldu. Biyolojik ritimlerinin düzenli olabilmesi için 12 saat yapay 1şı, 12 saat karanlık ortam sağlandı.

Östrüsun dönemlerini belirlemek için Mallenby ve ark. (7) nın kullandıkları vajinal smear yöntemi uygulandı. Vajinal smear alınmadan önce sıçanların vulva etrafı \% 70'lik alkolle silinip temizlendikten sonra steril ve tek kullanımlık tahta çubuklarla vajina duvarından nazik bir şekilde sürüntü alındı. Alınan sürüntü temiz bir lam üzerine yayıldı, üzerine \% 70'lik etil alkol dökülerek beş dakika süreyle tespit edildi. Havada kurutulan sürme preparatlar \% l'lik olarak hazırlanan metilen mavisi ile 5 dakika boyandı.

Farklı siklus dönemlerindeki sıçanlar yüksek doz eter ile uyutularak dekapite edildi. Abdominal diseksiyon ile uterusları alınarak formol-alkol tespit sıvısında 24 saat süreyle tespit edildi. Tespit sıvısındaki doku örneklerine bilinen histolojik doku takibi işlemleri uygulandı. Genel doku takibinden sonra dokular paraplastta bloklandılar. Hazırlanan bloklardan rotary mikrotom (Leice RM 2135, Germany) ile alınan $6 \mu$ kalınlığındaki kesitlere plazma hücrelerini belirlemek için metil green-pironin boyama yöntemi uygulandı (8). Hazırlanan preperatlar Nikon Optiphot iki model araştırma mikroskobunda incelendi ve gerekli görülen bölgelerin fotoğrafları çekildi. 


\section{Plazma hücre sayımı}

Uterus doku kesitinin, metil green-pironin boyama yöntemi ile boyanan preperatlarında plazma hücrelerinin sayısal dağılımını saptamak için yapılan hücre sayımlarında 100 kare oküler mikrometre (eyepiece graticule) kullanıldı. Plazma hücreleri, 40'lık objektif büyütmesinde 100 kare içerisine düşen birim alanda sayıldı. Her kesitte endometriyumda rastgele seçilen sekiz farklı bölgede hücre sayımları yapıldı. Bu şekilde seri kesitlerin sayılması ile elde edilen rakamların aritmetik ortalaması alındı. Böylece 100 kare oküler mikrometrenin kapsadığı alandaki ortalama plazma hücre sayısı saptand1. Mikrometrik lam yardımıyla 40'lık objektif büyütmesi için 100 kare oküler mikrometrenin alanı saptandı (9). Daha sonra tüm sayısal veriler, $1 \mathrm{~mm}^{2}$ lik birim alandaki plazma hücre sayısına dönüştürülerek hesaplandı.

\section{İstatistiksel Analizler}

Östrüs siklusunun proöstrüs, östrüs, metöstrüs ve diöstrüs evrelerinde, plazma hücre sayılarının genel istatistiksel değerlendirilmesi ve bu evreler arası varyans analizleri (ANOVA) SPSS (IBM-PC) paket programında gerçekleştirildi $(10,11)$.

\section{Bulgular}

Humoral savunmada rol oynayan plazma hücrelerinin, östrüs siklusu dönemlerine göre değişimler gösterdiği belirlendi. Plazma hücrelerinin en fazla sayıda proöstrüs döneminde bulunduğu, bu sayının sırasıyla östrüs, metöstrüs ve diöstrüs evrelerine doğru oldukça azaldığg belirlendi (Tablo1). 
Tablo 1. Östrüs siklusu evrelerinde endometriyumda plazma hücrelerinin dağılımı.

\begin{tabular}{|l|c|c|}
\hline Ostrüs Evreleri & $\mathrm{n}$ & $\begin{array}{c}\text { Plazma Hücresi Adet } / \mathrm{mm}^{2} \\
\text { Aritmetik Ortalama }(\mathrm{x} \pm \mathrm{SH})\end{array}$ \\
\hline Proöstrüs & 7 & $57.14 \pm 1.82^{\mathrm{a}}$ \\
\hline Ostrüs & 7 & $42.29 \pm 1.27^{\mathrm{b}}$ \\
\hline Metöstrüs & 7 & $28.57 \pm 0.90^{\mathrm{c}}$ \\
\hline Diöstrüs & & $14.29 \pm 0.87^{\mathrm{d}}$ \\
\hline
\end{tabular}

Plazma sayıları sütunundaki farklı östrüs evrelerininde farklı harf taşıyan grup ortalamaları istatistiksel olarak önemli farklılı̆̆a sahiptir $(\mathbf{p}<0.05)$.

Siklusun bütün dönemlerinde plazma hücrelerinin özellikle bezler ve damarlar etrafında bulunmakla birlikte endometriyumun farklı bölgelerinde değişik yoğunlukta bulunduğu tespit edildi (Resim 1-4).

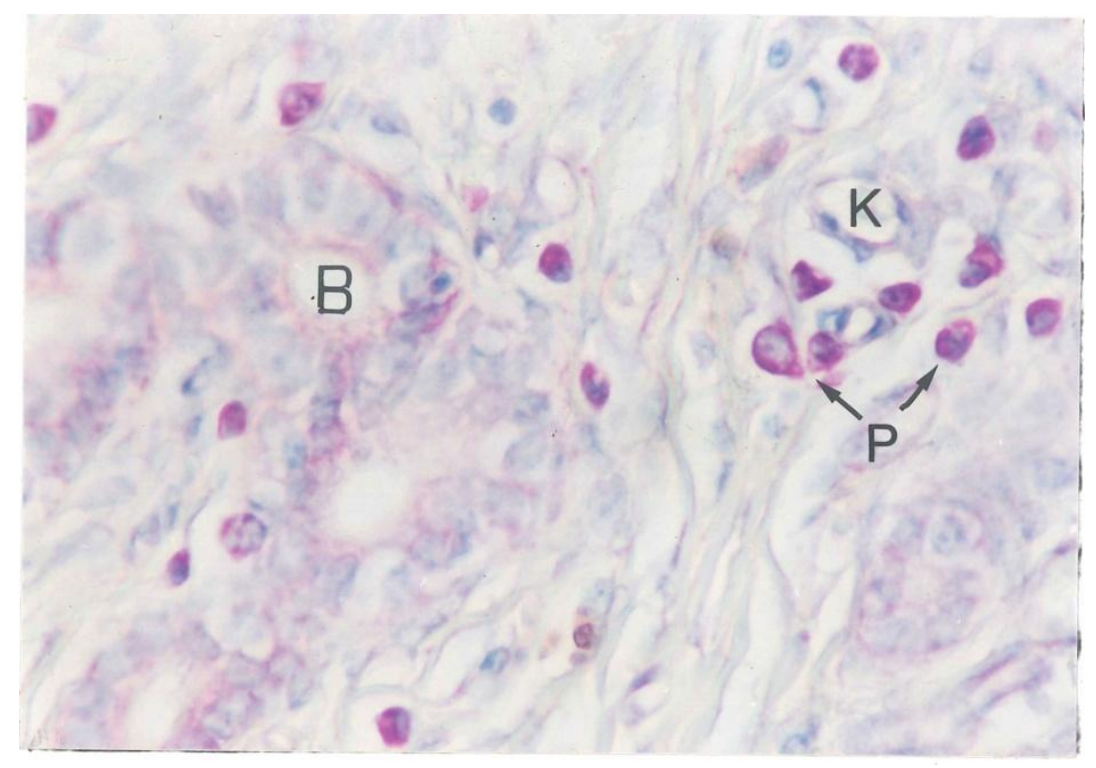

Resim 1. Proöstrüs evresinde endometriyumda daha çok damarlar ve bezler etrafında lokalize plazma hücreleri (P). B: Bez, K: Kapiller. Metil green - pironin, X 720 


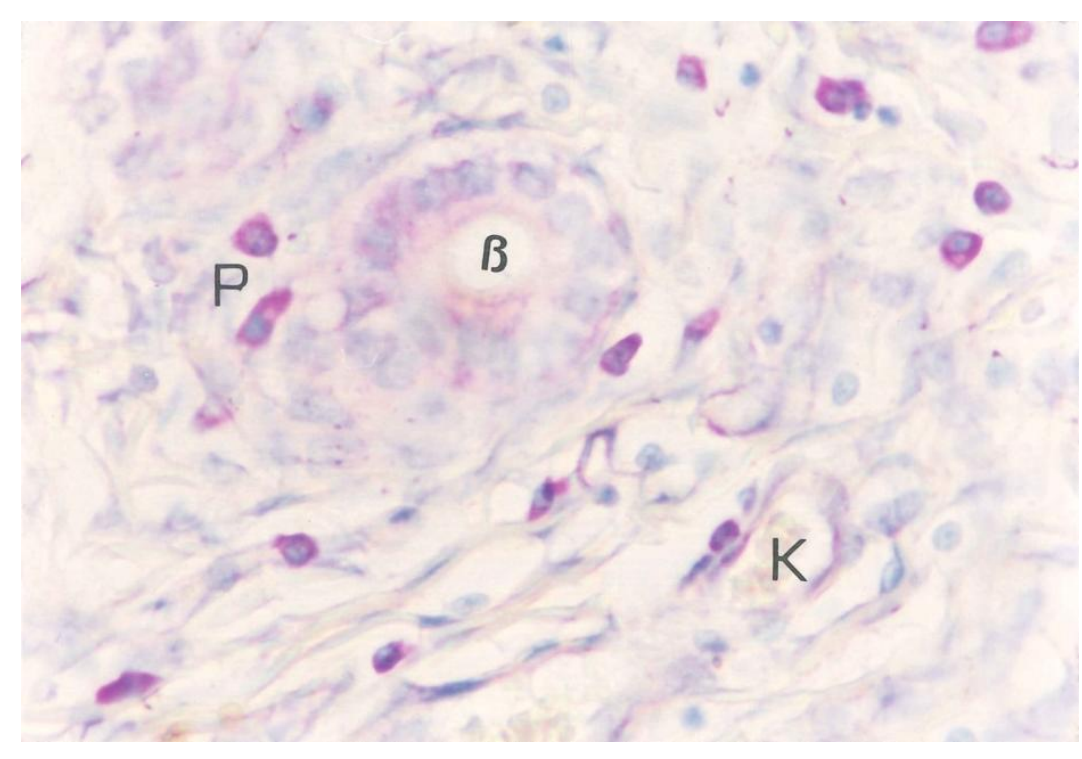

Resim 2. Östrüs evresinde endometriyumda dağılmış plazma hücrelerinin (P) görünümü. B: Bez, K: Kapiller, Metil green - pironin, X 720.

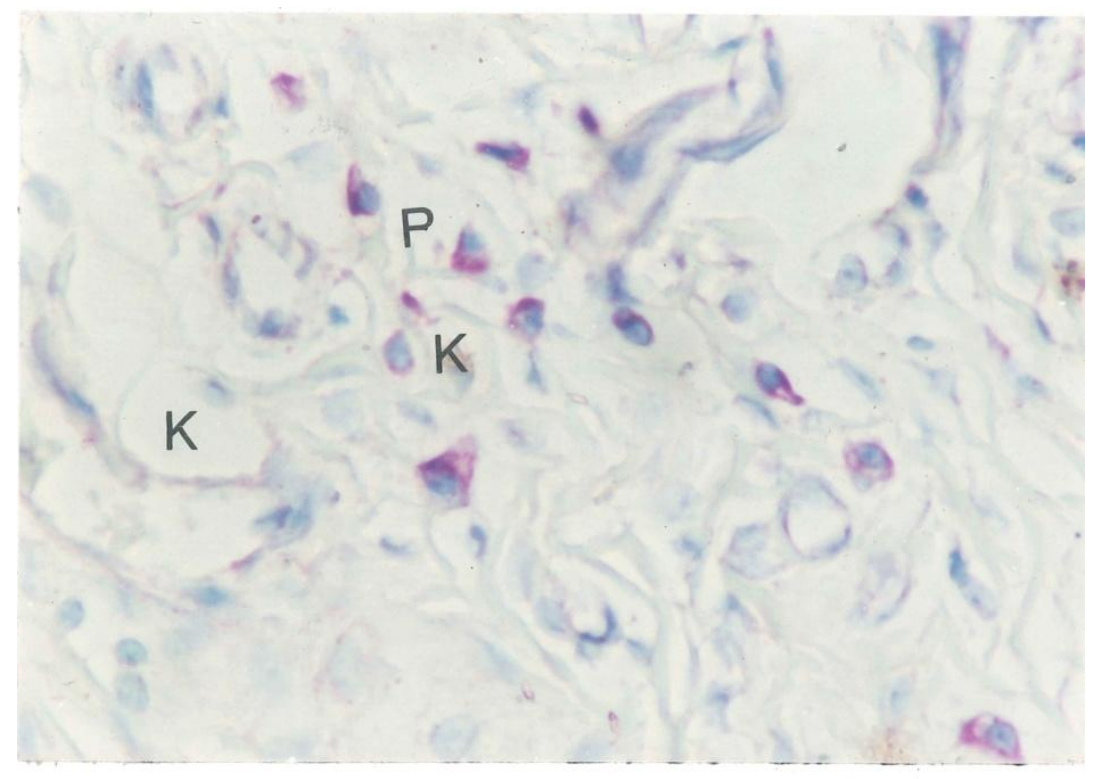

Resim 3. Metöstrüs evresinde endometriyumda damarlar etrafinda lokalize plazma hücreleri (P). K: Kapiller. Metil green - pironin, X 720. 


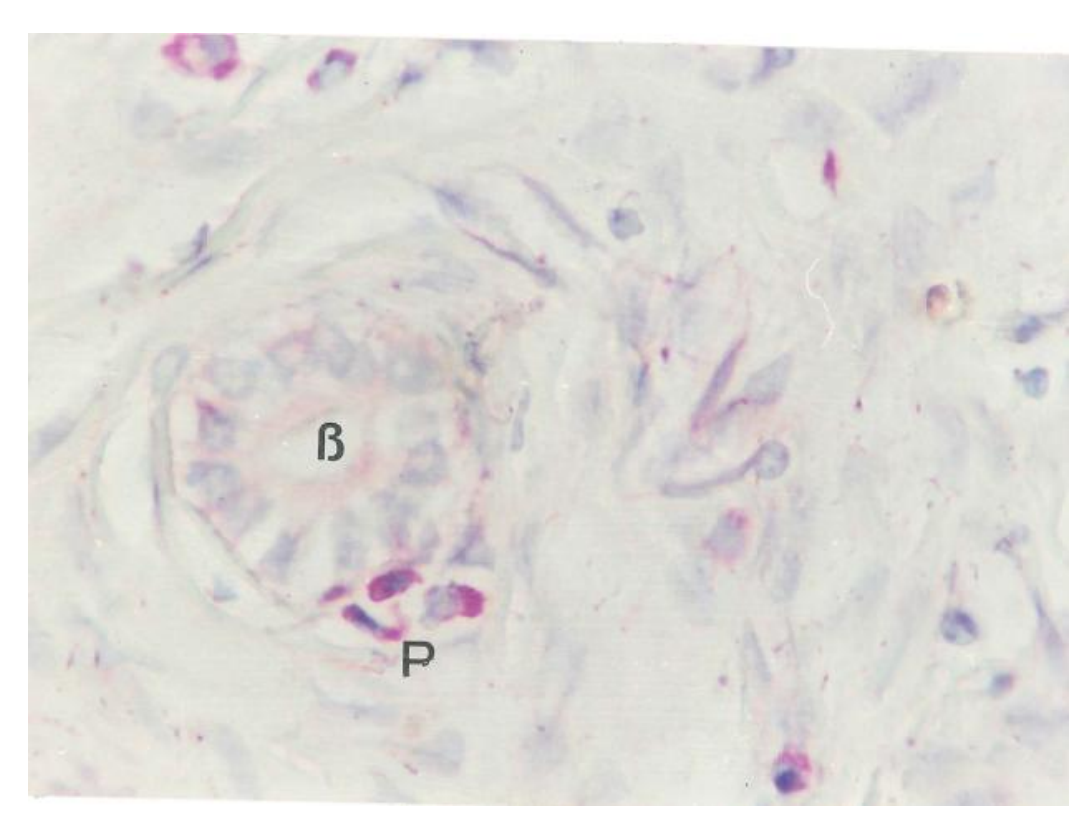

Resim 4. Diöstrüs evresinde endometriyumda gittikçe azalan ve bezler etrafında lokalize plazma hücreleri (P). B: Bez, Metil green - pironin, X 720.

\section{Tartışma.}

$\mathrm{Bu}$ çalışma, östrus siklusunun farklı evrelerine göre sıçan endometriyum dokusundaki humoral savunma sistemi hücrelerinin dağılımını belirlemek amacıyla yapild1.

Rachman ve ark. (12), Canning ve ark. (4) ile Shaikh (13), farelerde yaptıkları çalışmalarda, plazma hücrelerinin yoğun olarak proöstrüsde, diostrüsde ise az sayıda hücreye rastlandığını bildirmişlerdir. Plazma hücrelerinin proöstrüsde endometriyumun stromasmda homojen bir şekilde dağıldığı bildirilmiştir Yapılan bir çalışmada (4), farelerde proöstrüsde plazma hücrelerinin endometriyumda stromada daha çok uterus bezleri ve lümende fazla sayıda görüldüğü, hücrelerin subepitelde genellikle kümeler halinde, bezler çevresinde ise dağınık bir şekilde bulunduğu belirtilmiştir. Diğer plazma hücrelerinin ise stromada rasgele dağılmış olup, miyometriyuma yakın olarak 
bazal endometriyumda yer aldı̆̆ı kaydedilmiştir. Parr ve ark (14) ise, farelerde plazma hücrelerinin östrüs evresinde genellikle bezler çevresinde bulunduğunu bildirmiştir. Markovic ve ark. (2)'na göre, plazma hücrelerinin sayısı sıçanlarda özellikle östrüs ve metöstrüs evrelerinde artmaktadir. Hücre sayılarında östrüs ye metöstrüs evrelerine göre, proöstrüs ve diöstrüs evrelerinde azalma olduğu bildirilmiştir. Aynı araştırıcı, metöstrüsde çok sayıda plazma hücresinin lamina propriyada ve gruplar halinde uterus bezlerinin etrafinda yer aldığını, diöstrüsde ise plazma hücrelerinin bezler arası stromada bulunduğunu bildirmiştir. Hussein ve ark. (15)'na göre domuzlarda artan östradiol etkisine bağlı olarak plazma hücresi sayısı östrüs evresinde artmaktadır. İneklerde plazma hücresi sayısının östrüsde en fazla sayıya ulaştığı (16), atlarda ise endometriyumda bulunan plazma hücrelerinin sayılarının sekretorik fazda arttığı bildirilmektedir (17). Wira ve Sandoe (18), siçanlarda plazma hücrelerinin siklusun her aşamasında görüldüğ̈nü, hücre yoğunluğunun özellikle proöstrüsde arttığını ancak diöstrüsde azaldığını belirtmiştir. Yapılan bir calışmada (19), sıçanlarda östrüs siklusu sırasında plazma hücrelerinin sayısının proöstrüsde arttığı, diöstrüsde ise bu saynın azaldığı bildirilmiştir. Bir başka çalışmada, sıçanlarda plazma hücresi sayısının östrüs ve metöstrüsde arttığı, proöstrüs ve diöstrüsde azaldığı bildirilmiştir (2).

Bazı araştırmacılar farelerde $(4,12)$ ve sıçanlarda $(18,19)$ yaptıkları çalışmalarda, plazma hücrelerinin yoğun olarak proöstrüste görüldüğünü, diöstrüste ise az sayıda hücreye rastlandığını bildirmişlerdir. Hussein ve ark. (15)'na göre domuzlarda, ayrıca Whitmore ve Archbald (20)'a göre ineklerde, plazma hücresi sayısının östrüste en fazla sayıda bulunduğu, Mitchell ve ark. (21)'na göre ise atlarda, bunun tam tersi bir durumun söz konusu olduğu belirtilmektedir. Markovic ve ark. (2) ise, plazma hücreleri sayısının östrüs ve metöstrüs döneminde arttığını, diöstrüs ve proöstrüs döneminde ise azaldığını ifade etmişlerdir. Sıçanlarda yapılan bu çalışmada, plazma hücrelerinin en fazla sayıda proöstrüste görüldüğü, 
bu sayının sırasıyla östrüs, metöstrüs ve diöstrüs dönemlerine doğru gittikçe azaldığı belirlendi. $\mathrm{Bu}$ araştırmadaki bulgular, yukarıdaki arastırıcıların verileriyle benzerlik göstermektedir. Ancak, Mitchell ve ark. (21)'nın atlardaki plazma hücrelerinin sekretorik fazda artması ile Markovic ve ark. (2)'nın sıçanlardaki plazma hücrelerinin özellikle proöstrüs döneminde azalması ve metöstrüs döneminde ise artması verileriyle farklılık göstermektedir.

Rachman ve ark. (12)'na göre, farelerde plazma hücreleri endometriyumda homojen dağılırken; Canning ve ark. (4)'na göre farelerde, Markovic ve ark. (2)'na göre ise sıçanlarda plazma hücreleri endometriyumda dağınık bir şekilde bulunmakla birlikte özellikle bezler etrafinda kümeler oluşturduğu belirtilmektedir.

$\mathrm{Bu}$ çalışmada, plazma hücrelerinin lokalizasyonu Rachman ve ark. (12) ile farklılık gösterirken, diğer araştırıcılarla paralellik sergilemektedir.

$\underline{\text { Sonuç olarak, endometriyumdaki humoral savunma sistemi hücrelerinin, östrus siklusunun }}$ farklı evrelerinde değișik dağglımlar gösterdiği tespit edildi. Östrus siklusunun,,hormonal $\underline{\text { regülasyonun kontrolü altında birbirini takip eden farklı evreler içerdiği ve evreler arasındaki }}$ $\underline{\text { immunulojik farklılığın yine bu hormonların kontrolü altında ortaya çıktığg kanaatine varıldı. }}$ $\underline{\text { Diși cinsiyet hormonlarıyla üreme kanalındaki ilișkinin aydınlatılması için daha ileri }}$ çalıșmalara ihtiyaç olduğu düșüncesindeyiz.

Bu çalışma Yüzüncü Yıl Üniversitesi (1999) Sağlık Bilimleri Enstitüsü’nde Yüksek lisans tezi olarak yapılan çalışmanın verilerinden elde edilmiştir. Çalışma Yüzüncü Yıl Üniversitesi Araştırma Fonu tarafından 98.VF.67 numaralı proje olarak desteklenmiştir. 


\section{KAYNAKLAR}

1. Bonatz, G, Hansman L, Buchholz F, Mettler L, Radzun JH and Semm, K. Macrophage and lymphocyte subtypes in the endometrium during different phases of the ovarian cycle, Int. J. Gynecol. Obstet, 1992;37: 29 - 36.

2. Markovic Saljnikov D, Pavlovic M, Simic M. Morphometric investigations of plasmocytes and detection of immunoglobulins in the female rat genital tract during the oestrous cycle, Acta Veterinaria (Belgrad) 1997;47(2-3):107-114.

3. Hawk HW, Brinsfield TH, Turner GD, Whitmore GW and M. A. Norcross. Effect of ovarian status on induced acute inflammatory responses in cattle uteri, Am. J. Vet. Res. 1964;25: 362366.

4. Canning, B. M. and Billington, D. W. Hormonal regulation of immunoglobulins and plasma cells in the mouse uterus, J. Endocrin 1983; 97, 419 - 424.

5. Arda MO, Minbay A, Aydm N, Akay Ö, Îzgür M, Diker KS. immunoloji, 1. Baskl, Medisan Yaymevi, Ankara 1994.

6. Head RJ and Gaede DS. la antigen expression in the rat uterus, Journal of Reproductive Immunology 1986;9:137-153.

7. Mallenby J, Dunyer J, Howkins C and Hithen C. Effect of Experimental limbic on the estrus cycle and reproductive succes in rat. Epilessiya 1991;34(2):220-227.

8. Bancroft, J. D., Cook, H. C. (1984) Manual of histological techniques, Churchill Livingstone, New York

9. Böck, P. (1989) Romeis Mikroskopische Tecknik, 17. Aufl., Urban und Schwarzenberg, Munchen, Wien, Baltimore, 325 - 332.

10. .SPSS for Windows, Release 6.1 Standart Version, 1994,USA.

11. Akgül, A. (1997) Tlbbi Ara\$lrmalarda Îstatistiksel Analiz Teknikleri, SPSS Uygulamalarl, YÖK Matbaasl, Ankara

12. Rachman F, Casimiri V, Psychoyos A and Bernard O. immunoglobulins in the mouse uterus during the oestrous cycle, J. Reprod. Fert. 1983;69:17-21.

13. Shaikh, AA. Estrone and estradiol levels in the ovarian venous blood from rats during the estrous cycle and pregnancy, Biology of Reproduction. 1971;5:297-307.

14. Parr BM and Parr LE. Immunohistochemical localization of immunoglobulins $A, G$ and $M$ in the mouse female genital tract, J. Reprod. Fert. 1985;74:361-370.

15. Hussein, A. M.,Newby, T.J. and Bourne, F.G. Immunohistochemical studies of the local immune system in the reproductive tract of the sow.J.Reprod.Immunol.5:1-15(1983) 
16. Whitmore, H. L., and Archbald, L. F. Demonstration and guantitation of immunoglobulins in bovine serum, follicular fluid, and uterine and vaginal secretions with reference to bovine viral diarrhea and infectious bovine rhinotracheitis. Am. J. Vet. Res. 1977;38: 455-457.

17. Mitchell, G. , Liu, I. K. , Perryman, L. E. , Stabenfeldt, G. H. and Hughes, J. P. Preferential production and secretion of immunoglobulins by the eguine endometrium-a mucosal immune system. J. Reprod. Fertil. 1982;32:161-168.

18. Wira, C. R. and Sandoe, C. P. (1980) Hormonal regulation of immunoglobulins influence of estradiol on immunoglobulins A and $\mathrm{G}$ in the rat uterus, Endocrinology, 106, 1020-1026.

19. Wira, C. R. and Sandoe, C. P. Sex steroid hormone regulation of $\operatorname{IgA}$ and $\operatorname{IgG}$ in rat uterine secretions, Nature, Lond. 1977;268:534-535.

20. Whitmore HL, Archbald LF. Demonstration and quantitation of immunoglobulins in bovine serum, follicular fluid, and uterine and vaginal secretions with reference to bovine viral diarrhea and infectious bovine rhinotracheitis. Am J Vet Res. 1977 Apr;38(4):455-7

21. Mitchell CA, Brown S, Campbell JK, Munday AD, Speed CJ. Regulation of second messengers by the inositol polyphosphate 5-phosphatases. Biochem Soc Trans. 1996;24:994 1000 . 